\title{
Effect of an Educational Program on Maternity Nurses Knowledge and Attitude about Umbilical Cord Blood Banking and its Barriers
}

\section{Nahla Tawfiq Ahmed Elmarakby ${ }^{1}$, Hend Salah Eldein Mohammed ${ }^{2}$, Rehab Mohammed AbdEl-hady ${ }^{3}$ and Rehab Soliman Abd El Aliem ${ }^{4}$}

(1)B.Sc. of Nursing, 2011, Benha University, Egypt, (2) Professor of Obstetrics \& Gynecological Health Nursing, Faculty of Nursing - Zagzig University, Egypt, (3,4) Assistant Professor of Obstetrics \&Woman's Health Nursing, Faculty of Nursing -Benha University, Egypt

\section{Abstract}

Background: Umbilical cord blood banking is a surviving procedure that can increase life expectancy of end-stage or chronically ill patients. Aim of study: Was to evaluate the effect of an educational program on maternity nurses' knowledge and attitude about umbilical cord blood banking and its barriers. Design: A quasi-experimental pre-posttest research design was utilized. Setting: The study was conducted at Obstetrics and Gynecological departments at Benha University Hospital. Sampling: A convenient sample of 100 maternity nurses. Tools of data collection: Two main tools were used, I: A structure interviewing questionnaire which included 2 parts I) sociodemographic characteristics of maternity nurses and II) knowledge of maternity nurses regarding umbilical cord blood banking and its barriers and II: Modified Likert scale was adopted to assess the nurses' attitudes regarding to umbilical cord blood banking and its barriers. Results: There was a highly statistical significant difference between the results of immediate post program compared to pre program in favor of post program. Additionally, there were positive highly statistical significant correlations between total knowledge score and total attitude score pre and immediate post program. Conclusion: There was significant improving in maternity nurses' knowledge and attitude regarding umbilical cord blood banking and its barriers. Therefore, the research hypothesis was supported and the aim was achieved. Recommendations: Continuously planned in-service training programs related to cord blood banking must be established to develop nurses' knowledge, attitude in order to suit newly developed concepts in care.

Key word: Attitude, Barriers, Educational program, Maternity nurses, Knowledge, Umbilical cord blood banking.

\section{Introduction}

Umbilical cord is the main link and vital attachment, which is always represented as blood and emotional parenthood relationship (Sahoo \& Rana., 2020). The placenta was discarded with umbilical cord blood as medical waste. Over the past few decades, cord blood has been shown to contain stem cells and early precursor cells that can be used for life-saving stem cell transplantation for children and adults in need of a stem cell transplant (Gholap et al., 2018).

Umbilical Cord Blood (UCB) stem cells are similar to those found in the bone marrow. Moreover, the stem cells obtained from umbilical cord blood are less likely to be rejected in transplants than bone marrow stem cells. Several other benefits include easy collection and availability of cord blood stem cells, decreased transmission of diseases. Therefore, cord blood can be used for 
transplantation as an alternative to bone marrow (Philip \& Devis., 2017). Stem cells are special cells because stem cells are able to self-replicate and differentiate into other body cells. This enables the body to replenish tissue and repair itself so stem cells can help repair tissues, organs, blood vessels and provide the physicians with a way to treat many diseases that require stem cell transplants (Gholap et al., 2018).

Umbilical Cord Blood Banking (UCBB) is the process of collecting and storing umbilical cord blood, in the immediate period after the birth of a baby (Peberdy et al., 2018).Umbilical cord blood can be collected without causing any kind of harm to the mother or infant donor. Unlike embryonic stem cells these are not ethically controversial. As the newborn, is delivered, and the umbilical cord is divided, blood can be collected from the segment of cord still attached to the placenta. Stem cells retrieved from the blood in the remaining segment of the umbilical cord and placenta (Sahoo \& Rana., 2020).

Umbilical cord blood can be collected and stored either publicly or privately. Public cord blood banks operate in all developed countries, and within most developing countries. Public cord blood banks collect, transport, process, test and store cord blood units which have been Selflessly donated for allogeneic use, at no financial cost to the donating parents. The donated cord blood unit is not reserved for the use of the donating family, who relinquish their rights of ownership of the blood to the banking facility (Peberdy et al., 2018). A Private cord blood banks charge parents a fee for the collection, processing and storage of their infant's cord blood for exclusive autologous or family use (Sahoo \& Rana., 2020).

Researchers found that many barriers are identified by participants to decide not to have UCB collected that included concerns about the safety of the mother and neonate, beliefs about the placenta, threats against confidentiality, rejection of UCB, and the influence of fathers such as the cost of cord blood banks, policies and procedures of their hospitals, the time needed to educate the mothers, lack of nurses' knowledge about UCBB, cultural believes of the placenta ,pregnancy is a difficult time to make decisions, lack of mothers' knowledge about UCBB and religious barriers (Moustafa \&Youness., 2015).

Maternity nurses are integral part of health care providers in all phases of life. Their role in cord blood collection is concentrated in the preparation, collection, tagging and packing of the blood tube. Nurses have a specified role in patient teaching, as they have a reliable source of health information, so they must be aware of the latest trends in medical diagnosis and treatment (Mansour et al., 2020).

\section{Significance of the study}

Umbilical cord blood banking is a new approach in medical science and it is the most advanced technology available globally to repair the body's failing system; most of the clients are unaware about this clinical entity. By 2014, the international cord blood banking network comprised over 160 public cord blood banks in 36 countries, with over 731,000 umbilical cord blood units stored (Sahoo \& Rana., 2020).

Nurses especially in maternity field have to be informed about the most modern advances and receive the required training. So that, increase the level of awareness regarding cord blood banking and its barriers among the staff nurses and accept a positive attitude will help in developing cord blood banking as an essential aspect of Egyptian healthcare team (Mansour et al., 2020).

Moreover, there are no researches in Obstetrics and Woman's Health Nursing 
department at Benha University, Faculty of Nursing studied effect of an educational program on maternity nurse's knowledge and attitude about umbilical cord blood banking and its barriers.

\section{Aim of the study}

The study aimed to evaluate the effect of an educational program on maternity nurses' knowledge and attitude about umbilical cord blood banking and its barriers.

\section{Research hypothesis:}

Application of an educational program on umbilical cord blood banking and its barriers would have a positive effect on maternity nurses' knowledge and attitude more than before application an educational program.

\section{Subjects and method}

\section{Study design:}

A quasi-experimental design (preposttest) was used to fulfill the aim of the study.

\section{Study setting:}

The study was conducted at Obstetrics and Gynecological departments at Benha University Hospital.

\section{Sample:}

a- Sample type: A convenient sample technique was used.

b- Sample size: All maternity nurses working in the Obstetrics and Gynecological departments at the time of the data collection were included in the study. The total numbers were 100 maternity nurses.

\section{Tools for data collection:}

Two main tools were used for data collection:

Tool (1): Structured questionnaire was developed by the researcher based on reviewing related literature and it was written in simple clear Arabic languages which cover two parts:

Part (I): Concerned with socio demographic data and contains 5 questions related age, educational qualification, occupation, years of experience, attended training courses on umbilical cord blood banking and its barriers.

Part (II): Concerned with knowledge of nurses regarding umbilical cord blood banking and its barriers. It was consisted of twenty seven questions divided into three sections:

\section{Section 1: Maternity nurses'} knowledge about umbilical cord blood: Used to assess the maternity nurses' knowledge about umbilical cord blood, it consisted of eight questions.

Section 2: Maternity nurses' Knowledge about umbilical cord blood banking: contained ten questions.

Section3: Maternity nurses' Knowledge about barriers of umbilical cord blood banking: Contained nine questions.

\section{Scoring system:}

Each item of knowledge questionnaire was take a score of (2) for complete correct answer, (1) for the incomplete corrected answer and (0) for incorrect answer. These scores were converted into percent score.

Knowledge score was classified into three categories as the following:

- A scoring of $<50 \%$ of the total score indicated poor knowledge.

- A scoring of $50-75 \%$ of the total score indicated fair knowledge.

- A scoring of $>75 \%$ of the total score indicated good knowledge.

Tool (2): Modified Likert scale was adopted from Rucinski et al, (2010) and Patyal et al, (2018) to assess the nurses attitude regarding 
to umbilical cord blood banking and its barriers, it includes 19 statement which divided into two parts:

$\mathbf{1}^{\text {st }}$ part: Contained eleven statements about umbilical cord blood banking and its barriers.

$2^{\text {nd }}$ part: Contained eight statements regarding considerations and recommendations about umbilical cord blood banking and its barriers.

\section{Scoring system:}

Scores of total attitude, a score of (2) grade was given for agree, a score of (1) grade was given for neutral and a score of (0) grade was given for disagree. The score of each item summed-up and then converted into a percent score. The total score was classified into:

-Positive behavior: $\geq 75$.

-Negative behavior: $<75 \%$.

\section{Tools validity and reliability}

Content validity of the tool was established after it revised by a jury of 3 experts specialized in related Nursing field and 2 experts specialized in Blood Banking. Pre-testing of the tools revealed that the tool was clear, feasible and there was no ambiguity in the language. Modifications were done accordingly based on their comments and remarks. Internal consistency and a reliability coefficient (Cronbach's alpha) the components of the questionnaire tested by SPSS software version 20.And it was 0.832 for knowledge assessment part, 0.796 for modified Likert scale.

\section{Pilot study}

Ten nurses (about ten percent of the total sample) were included in the pilot study to test the clarity and applicability of the study tools. It was done to estimate the period required to fill the questionnaire, evaluate applicability \& clarity of tools and assess feasibility of field work. Questionnaire weren't requiring modifications. Nurses involved in the pilot study were included in the study.

\section{Ethical consideration:}

-The research approval was obtained from Scientific Research Ethical Committee, Faculty of Nursing at Benha University before starting the study. Each nurse was informed about the study aim then oral consent was obtained before starting the data collection. Confidentiality was ensured throughout the study process, and the maternity nurses were assured that all data was used only for research purpose. Each nurse was informed that participation is voluntary and free to withdraw from the study at any time or refuses to answer specific question without giving any reason.

\section{Field work:}

The study was carried out from the beginning of September 2020 till the end of November 2020. The Preparatory phase was the first phase of the study and it was included reviewing current and related literatures. Also, theoretical knowledge of various aspects of the study using books, articles, periodicals and magazines and internet to develop tools for data collection.

The following phases were adopted to fulfill the aim of current study: assessment, implementation, and evaluation phases.

\section{Assessment phase}

- The researcher visited the Obstetrics and Gynecological departments during the (morning and afternoon shifts) three days each week alternately for twelve weeks for conducting the program.

- The researcher had introduced themselves, greeted each nurse and explains the aim of the study for obtaining the formal consent. Then the researcher interviewed the nurses for 30 minutes and collects the baseline data. 
- Pre-test was carried out to evaluate nurses' knowledge and attitude regarding the umbilical cord blood banking and its barriers for further comparison after conducting the educational program.

- Based on the data that has collected from pre-test assessment, the educational program sessions were conducted.

\section{Implementation phase}

- Six sessions were provided in Arabic language to suit to different educational levels of maternity nurses.

- The teaching methods were included (brainstorming, lectures and group discussion). In addition, the researchers were able to direct the group by asking stimulating questions, listen to all comments and opinions and from time to time summarizing important points.

- The teaching media were included visual aids as posters, PowerPoint presentation and video.

- The program encompassed six planned sessions and was implemented according to job load, nurses' shifts and their intellectual and physical willingness. The sessions were repeated to each subgroup included (45nurses). Each session continued for 30-45 minutes including time for discussion and differ according to the nurses' recognition, comments and feedback.

1st session: An orientation about the program and its aims were clarified at the beginning of the first session. It covered information about the umbilical cord such as definition \& anatomy and give simple introduction about umbilical cord blood banking.

2nd session: It covered knowledge about umbilical cord blood such as definition of stem cells, diseases that treated by umbilical cord blood cells, advantage and disadvantage of umbilical cord blood cells . 3rd session: It aimed for increasing knowledge about Contraindication of umbilical cord blood collection and nursing role in umbilical cord blood collection.

4th session: : It aimed for increasing knowledge about umbilical cord blood banking such as definition of umbilical cord blood banking and types of umbilical cord blood banking.

5th session: It aimed for increasing knowledge about recommended procedures during umbilical cord blood banking and improving attitude about umbilical cord blood banking.

6th session: It aimed for increasing knowledge about barriers of umbilical cord blood banking. This session was applied for revising all data provided at the previous sessions and discusses the answers of all questions. Instructional booklets were distributed at the end of the sessions.

- At the beginning of each session, feedback was given about the previous one.

\section{Evaluation phase}

At this phase, the researcher had distributed the post-test to evaluate the knowledge and attitude of the maternity nurses by using the same predesigned tools to compare the difference between pre and posttest results and evaluate the effect of the implemented an educational program and compare

\section{Statistical analysis:}

The data were coded, computed and statistically using version 20 SPSS program (statistical package of social sciences). Data were presented as frequency and percentages (qualitative variables) and mean $\pm \mathrm{SD}$ (quantitative continuous variables). Test of significance $(€ \mathrm{FET}=$ Fisher Exact Test and paired $\mathrm{t}$ test) was applied to test the study hypothesis. Correlation coefficient was calculated between knowledge, and attitude scores. A statistically significant difference 
was considered at $\mathrm{p}$-value $(\mathrm{P} \leq 0.05)$, and a highly statistically significant difference was considered at $p$-value $(p \leq .001)$.

\section{Results}

Table (1): Shows that, more than half of studied maternity nurses $55 \%$ aged 25 to 30 years with a mean \pm SD $31.95 \pm 6.81$. As regards the educational level, the half of studied nurses $50 \%$ is diploma. Most of studied nurses $86 \%$ are bedside nurses. Also, more than three quarters of the studied nurses $83 \%$ had experience more than 10 years with a mean \pm SD $12.39 \pm 4.63$. There no one of them was training about cord blood banking and its barriers.

Figure (1): Shows that, minority of the studied maternity nurses $2 \%$ had good knowledge regarding umbilical cord blood banking and its barriers preprogram which increased to $85 \%$ post program.

Figure (2): Reveals that, less than tenth of the studied nurses $8 \%$ had positive attitude regarding umbilical cord blood banking and its barriers preprogram which increased to $92 \%$ immediate post program.

Table (2): Shows that, there was a positive highly statistically significant correlation between total knowledge score and total attitude score at pre and immediate post program $(\mathrm{P} \leq 0.001)$.
Table (3): Reveals that, there was a highly positive statistical significant relation between studied maternity nurses' total knowledge and age, educational level and years of experience at preprogram phase $(\mathrm{P} \leq$ 0.001). At the post program phase, there was positive statistical significant relation between studied maternity nurses' total knowledge and educational level. Also, there was a highly positive statistical significant relation between studied maternity nurses' total knowledge and years of experience at immediate post program. Meanwhile, there was no statistical significant relation between studied nurses' total knowledge and occupation pre and immediate post program $(\mathrm{P}>0.05)$.

Table (4): Demonstrates that, there was a highly positive statistical significant relation between studied maternity nurses' attitude and age at preprogram phase $(\mathrm{P} \leq$ 0.001). Also, there was a highly statistical significant relation between studied maternity nurses' attitude and years of experience at immediate post program. On the other hand, there was a positive statistical significant relation between studied maternity nurses' attitude' and educational level pre and immediate post program $(\mathrm{P} \leq 0.05)$. Also, there was a positive statistical significant relation between studied nurses' attitude and years of experience at preprogram phase. 
Table (1): Distribution of the studied maternity nurses socio-demographic characteristics $(\mathbf{n}=\mathbf{1 0 0})$

\begin{tabular}{|c|c|c|}
\hline Characteristics parameters & No. & $\%$ \\
\hline \multicolumn{3}{|c|}{ Age $($ years $)$} \\
\hline$<25$ & 4 & 4.0 \\
\hline $25: 30$ & 55 & 55.0 \\
\hline$>30$ & 41 & 41.0 \\
\hline Mean \pm SD & \multicolumn{2}{|c|}{$31.95 \pm 6.81$} \\
\hline \multicolumn{3}{|c|}{ Educational level } \\
\hline Diploma & 50 & 50.0 \\
\hline Technical institute & 32 & 32.0 \\
\hline Bachelor's degree & 15 & 15.0 \\
\hline Postgraduate studies & 3 & 3.0 \\
\hline \multicolumn{3}{|c|}{ Occupation } \\
\hline Bedside nurse & 86 & 86.0 \\
\hline Staff nurse & 10 & 10.0 \\
\hline Nurse supervisor & 4 & 4.0 \\
\hline \multicolumn{3}{|c|}{ Years of experience } \\
\hline$<5$ years & 5 & 5.0 \\
\hline $5: 10$ years & 12 & 12.0 \\
\hline$>10$ years & 83 & 83.0 \\
\hline Mean \pm SD & \multicolumn{2}{|c|}{$12.39 \pm 4.63$} \\
\hline \multicolumn{3}{|c|}{ Have any training courses? } \\
\hline No & 100 & 100.0 \\
\hline
\end{tabular}

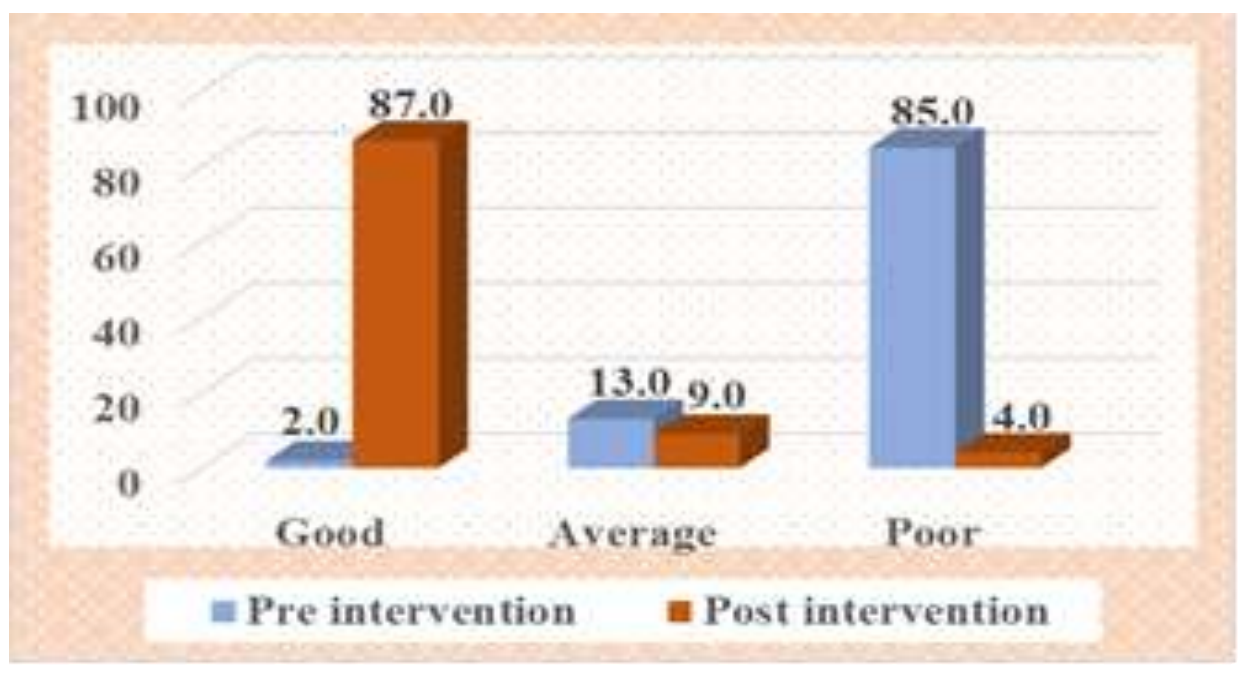

Figure ( 1 ): Distribution of the studied nurses according to total knowledge level regarding umbilical cord blood banking and its barriers pre and immediate post program $(n=100)$. 
Effect of an Educational Program on Maternity Nurses Knowledge and Attitude about Umbilical Cord Blood Banking and its Barriers

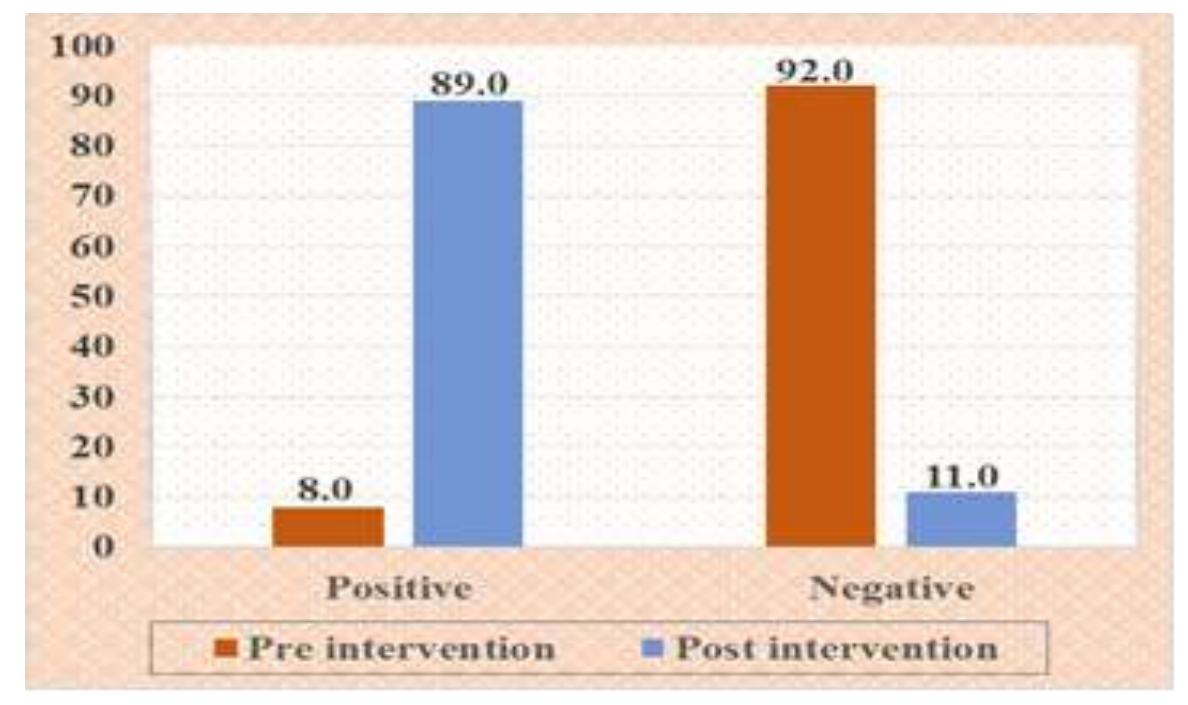

Figure ( 2 ): Distribution of the studied nurses according to total attitude level regarding umbilical cord blood banking and its barriers pre and post program $(\mathbf{n}=\mathbf{1 0 0})$

Table (2): Statistically Correlation between studied maternity nurses total knowledge and attitude scores about umbilical cord blood banking and its barriers pre and post program $(\mathbf{n}=\mathbf{1 0 0})$

\begin{tabular}{|c|c|c|c|}
\hline \multirow{2}{*}{\multicolumn{2}{|c|}{ Variable }} & \multicolumn{2}{|c|}{ Total knowledge score } \\
\hline & & $\mathbf{R}$ & P value \\
\hline Total attitude score & $\begin{array}{l}\text { Pre program } \\
n=100 \\
\text { Post } \\
n=100\end{array}$ & 0.368 & $0.000 * *$ \\
\hline
\end{tabular}


Table (3): Relation between of the studied nurses socio-demographic characteristics and level of knowledge about umbilical cord blood banking and its barriers pre and post program $(\mathbf{n}=\mathbf{1 0 0})$

\begin{tabular}{|c|c|c|c|c|c|c|c|c|c|c|c|c|}
\hline Total & \multicolumn{6}{|c|}{ Pre program } & \multicolumn{6}{|c|}{ Post program } \\
\hline score & \multicolumn{2}{|c|}{$\begin{array}{c}\text { Good } \\
n=2\end{array}$} & \multicolumn{2}{|c|}{$\begin{array}{c}\text { Average } \\
n=13\end{array}$} & \multicolumn{2}{|c|}{$\begin{array}{l}\text { Poor } \\
n=85\end{array}$} & \multicolumn{2}{|c|}{$\begin{array}{l}\text { Good } \\
\mathbf{n}=87\end{array}$} & \multicolumn{2}{|c|}{$\begin{array}{c}\text { Average } \\
n=9\end{array}$} & \multicolumn{2}{|c|}{$\begin{array}{c}\text { Poor } \\
n=4\end{array}$} \\
\hline $\begin{array}{l}\text { demography } \\
\text { characteristics }\end{array}$ & No & $\%$ & No & $\%$ & No & $\%$ & No & $\%$ & No & $\%$ & No & $\%$ \\
\hline \multicolumn{13}{|c|}{ Age ( years) } \\
\hline $20<25$ & 2 & 100.0 & 1 & 7.7 & 0 & 0.0 & 4 & 4.6 & 0 & 0.0 & 0 & 0.0 \\
\hline $25<30$ & 0 & 0.0 & 10 & 76.9 & 45 & 52.9 & 51 & 58.6 & 4 & 44.4 & 0 & 0.0 \\
\hline$>30$ & 0 & 0.0 & 2 & 15.4 & 40 & 47.1 & 32 & 36.8 & 5 & 55.6 & 4 & 100.0 \\
\hline $\begin{array}{c}\text { FET } \\
\text { P value }\end{array}$ & \multicolumn{6}{|c|}{$\begin{array}{l}72.083 \\
0.000 * *\end{array}$} & \multicolumn{6}{|c|}{0.115} \\
\hline \multicolumn{13}{|c|}{ Educational level } \\
\hline Diploma & 0 & 0.0 & 1 & 7.7 & 49 & 57.6 & 93 & 44.9 & 9 & 100.0 & 4 & 100.0 \\
\hline Technical & 0 & 0.0 & 11 & 84.6 & 21 & 24.7 & 30 & 34.5 & 0 & 0.0 & 0 & 0.0 \\
\hline Bachelor's & 2 & 100.0 & 0 & 0.0 & 13 & 15.3 & 51 & 17.2 & 0 & 0.0 & 0 & 0.0 \\
\hline Postgraduate & 0 & 0.0 & 1 & 7.7 & 2 & 2.4 & 3 & 3.4 & 0 & 0.0 & 0 & 0.0 \\
\hline $\begin{array}{c}\text { FET } \\
\text { P value }\end{array}$ & \multicolumn{6}{|c|}{$\begin{array}{c}32.669 \\
0.000 * *\end{array}$} & \multicolumn{6}{|c|}{$\begin{array}{l}13.793 \\
0.032 *\end{array}$} \\
\hline \multicolumn{13}{|c|}{ Occupation } \\
\hline Bedside nurse & 2 & 100.0 & 11 & 84.6 & 73 & 85.9 & 73 & 83.9 & 9 & 100.0 & 4 & 100.0 \\
\hline Staff nurse & 0 & 0.0 & 1 & 7.7 & 9 & 10.6 & 10 & 11.5 & 0 & 0.0 & 0 & 0.0 \\
\hline Supervisor & 0 & 0.0 & 1 & 7.7 & 3 & 3.5 & 4 & 4.6 & 0 & 0.0 & 0 & 0.0 \\
\hline $\begin{array}{c}\text { FET } \\
\text { P value }\end{array}$ & \multicolumn{6}{|c|}{$\begin{array}{l}1.107 \\
0.893\end{array}$} & \multicolumn{6}{|c|}{$\begin{array}{l}2.443 \\
0.657\end{array}$} \\
\hline \multicolumn{13}{|c|}{ Years of experience } \\
\hline$<5$ years & 2 & 100.0 & 0 & 0.0 & 3 & 3.5 & 1 & 1.1 & 2 & 22.2 & 2 & 50.0 \\
\hline 5:10 years & 0 & 0.0 & 0 & 0.0 & 12 & 14.1 & 6 & 6.9 & 4 & 44.5 & 2 & 50.0 \\
\hline$>10$ years & 0 & 0.0 & 13 & 100.0 & 70 & 82.4 & 80 & 92.0 & 3 & 33.3 & 0 & 0.0 \\
\hline $\begin{array}{c}\text { FET } \\
\text { P value }\end{array}$ & \multicolumn{6}{|c|}{$\begin{array}{l}41.352 \\
0.000 * *\end{array}$} & \multicolumn{6}{|c|}{$\begin{array}{c}45.550 \\
0.000 * *\end{array}$} \\
\hline
\end{tabular}


Effect of an Educational Program on Maternity Nurses Knowledge and Attitude about Umbilical Cord Blood Banking and its Barriers

Table (4): Relation between total attitude score and socio-demographic characteristics pre and post program $(n=100)$

\begin{tabular}{|c|c|c|c|c|c|c|c|c|}
\hline \multirow{3}{*}{$\begin{array}{l}\text { Total attitude } \\
\text { score } \\
\text { Socio-demographic } \\
\text { characteristics }\end{array}$} & \multicolumn{4}{|c|}{ Pre program } & \multicolumn{4}{|c|}{ Post program } \\
\hline & \multirow{2}{*}{\multicolumn{2}{|c|}{$\begin{array}{c}\begin{array}{c}\text { Positive } \\
\mathrm{n}=\mathbf{8}\end{array} \\
\mathrm{No}\end{array}$}} & \multicolumn{2}{|c|}{$\begin{array}{c}\text { Negative } \\
n=92\end{array}$} & \multicolumn{2}{|c|}{$\begin{array}{c}\text { Positive } \\
n=89\end{array}$} & \multicolumn{2}{|c|}{$\begin{array}{c}\text { Negative } \\
\mathrm{n}=11\end{array}$} \\
\hline & & & No & $\%$ & No & $\%$ & No & $\%$ \\
\hline \multicolumn{9}{|c|}{ Age ( years) } \\
\hline $20<25$ & 2 & 25.0 & 1 & 1.1 & 4 & 4.5 & 0 & 0.0 \\
\hline $25<30$ & 5 & 62.5 & 50 & 54.3 & 51 & 57.3 & 4 & 36.4 \\
\hline$>30$ & 1 & 12.5 & 41 & 44.6 & 34 & 38.2 & 7 & 63.6 \\
\hline FET & \multirow{2}{*}{\multicolumn{4}{|c|}{$\begin{array}{c}15.920 \\
0.000^{* *} \\
\end{array}$}} & \multirow{2}{*}{\multicolumn{4}{|c|}{$\begin{array}{l}2.820 \\
0.244\end{array}$}} \\
\hline$P$ value & & & & & & & & \\
\hline \multicolumn{9}{|c|}{ Educational level } \\
\hline Diploma & 0 & 0.0 & 50 & 54.3 & 41 & 46.0 & 11 & 100.0 \\
\hline Technical & 5 & 62.5 & 27 & 29.4 & 30 & 33.7 & 0 & 0.0 \\
\hline Bachelor's & 2 & 25.0 & 13 & 14.1 & 15 & 16.9 & 0 & 0.0 \\
\hline Postgraduate & 1 & 12.5 & 2 & 2.2 & 3 & 3.4 & 0 & 0.0 \\
\hline FET & \multirow{2}{*}{\multicolumn{4}{|c|}{$\begin{array}{l}10.071 \\
0.018 * \\
\end{array}$}} & \multirow{2}{*}{\multicolumn{4}{|c|}{$\begin{array}{l}11.409 \\
0.010^{*} \\
\end{array}$}} \\
\hline$P$ value & & & & & & & & \\
\hline \multicolumn{9}{|c|}{ Occupation } \\
\hline Bedside nurse & 7 & 87.5 & 79 & 85.8 & 75 & 84.3 & 11 & 100.0 \\
\hline Staff nurse & 0 & 0.0 & 10 & 10.9 & 10 & 11.2 & 0 & 0.0 \\
\hline Supervisor & 1 & 12.5 & 3 & 3.3 & 4 & 4.5 & 0 & 0.0 \\
\hline FET & \multirow{2}{*}{\multicolumn{4}{|c|}{$\begin{array}{l}2.442 \\
0295\end{array}$}} & \multirow{2}{*}{\multicolumn{4}{|c|}{$\begin{array}{l}2.012 \\
0.366\end{array}$}} \\
\hline P value & & & & & & & & \\
\hline \multicolumn{9}{|c|}{ years of experience } \\
\hline$<5$ years & 2 & 25.0 & 3 & 3.3 & 1 & 1.1 & 4 & 36.4 \\
\hline 5:10 years & 0 & 0.0 & 12 & 13.0 & 9 & 10.1 & 3 & 27.2 \\
\hline$>10$ years & 6 & 75.0 & 77 & 83.7 & 79 & 88.8 & 4 & 36.4 \\
\hline $\begin{array}{l}\text { FET } \\
\text { P value } \\
\end{array}$ & \multicolumn{4}{|c|}{$\begin{array}{c}8.067 \\
0.018 * \\
\end{array}$} & \multicolumn{4}{|c|}{$\begin{array}{c}29.957 \\
0.000 * *\end{array}$} \\
\hline
\end{tabular}




\section{Discussion}

The aim of present study was to evaluate the effect of an educational program on maternity nurses' knowledge and attitude about umbilical cord blood banking and its barriers. The current study result supported the stated hypothesis as the application of an educational program about umbilical cord blood banking and its barriers will have positive effect on maternity nurses' knowledge and attitude more than before application an educational program.

Umbilical cord blood is the remaining blood in the placenta and umbilical cord at birth, the cord blood has several benefits as it consists of several and great hematopoietic stem cells, Current statistics have proved that umbilical cord blood cells can totally treat nearly eighty diseases and more than fifty thousand transplants have been successfully implemented worldwide. Umbilical cord blood is a source of stem cells is being progressively used for treating many diseases including immune system disease, blood cell and genetic disorders, leukemia, myelomas, lymphomas Peberdy et al., (2018).

The discussion of the current study will be categorized under five main parts: general characteristic of maternity nurses, maternity nurses' Knowledge, maternity nurses' attitude, maternity nurses' mean scores, correlation between the study variables.

The current study results revealed that about more than half of studied sample were in age group 25 to 30 years old with a mean age of $31.95 \pm 6.81$ years. These findings were matched with Fadeel, et al., (2017) who conducted study about" Effect of an educational Guideline on Maternity Nurses Knowledge regarding process of cord blood collection " at Minia university and indicated that about three quarters of studied sample $(n=78)$ were in age group 25 to 30 years. This is in the same line with Pinto and
Pushapaveni, (2018) in their study about " Evaluate the Cord Blood for Stem Cell Therapy in Terms of Knowledge among Staff Nurses in Selected Hospitals at Bangalore " and reported that the majority of the participants $(n=50)$ fall between the ages of 21-30 years.

Regarding educational level, the finding of the present study showed that half of studied sample had nursing diploma $50 \%$. This finding was congruent with Mansour et al., (2020) ) in their study about " Effect of an Educational Program on Nurses' Knowledge and Attitudes Regarding Umbilical Cord-blood Stem Cells Preservation " and founded that almost half of the participants $(n=128)$ had nursing diploma 45.3\%. Also, this result congruent with Fadeel, et al., (2017) who showed that $46.2 \%$ had nursing secondary school. This finding of different study setting showed that half of nurses had nursing diploma.

As regards the occupation, the finding of the present study clarified that majority of maternity nurses $86 \%$ were bedside nurses. This finding was agreement with Moustafa \& Youness, (2015) in their study about " Nurses' knowledge about umbilical cord blood banking and it's barriers " at Assuit university clarified that most of studied sample $(n=150)$ were practice nurses $75.3 \%$. But, this result disagreement with Mansour et al., (2020) who indicated that practice nurses were $37.5 \%$ and the other were $38.8 \%$ are head nurses and $24.2 \%$ are staff nurses.

The finding of the present study may be due to hospital requirements.

Regarding years of experience, the current study illustrated that the most of studied sample had experience more than 10 years with a mean $12.39 \pm 4.63$ years. These findings were supported by Moustafa \& Youness, (2015) who stated that $42.0 \%$ of studied sample had 10 to 20 years of 
experience and $34.7 \%$ more than 20 years of experience. While on the contrary, a study done by Patyal et al., (2018) " A study to assess the knowledge and attitude of nurses regarding stem cell and umbilical cord blood banking in selected hospital of Ambala, Haryana" in India and showed that $1 \%$ of studied sample $(n=170)$ had 10:15 years of experience.

The results of current study revealed that all studied sample didn't attend any special scientific courses on umbilical cord blood banking and its barriers. This finding is in congruence with that of Amin et al, (2016) in their study about " Knowledge regarding umbilical cord stem cell therapy among staff nurses with the view to develop selfinstructional module " at Mangaluru who found that $89 \%$ of their studied sample $(n=100)$ had no previous information regarding umbilical cord stem cell therapy. Moreover, current study were congruence with Khalil \& Sharshor., (2016) in the study conducted to "assess nurses' knowledge and attitude regarding application of stem cells therapy " in Tanta, Egypt and reported that the nurses $(\mathrm{n}=50)$ and found that approximately two third of the studied nurses in Pediatric Intensive Care Unit and the majority (92.0\%) of participant nurses' in hematological unit had no knowledge about stem cells.

This supported our study as there were no bias and the information gained will be due to effect of present educational program.

The present study revealed that $2 \%$ and $87 \%$ of studied nurses had good total knowledge score at preprogram and immediate post program phases respectively. While, it was revealed that $85 \%$ and $4 \%$ of studied nurses had poor total knowledge score at preprogram and immediate post program phases respectively. There was a highly statistical significant difference between the results of post-test compared to pre-test in favor of post-test, which improved from Mean \pm SD $12.36 \pm 4.10$ pre-program to $49.56 \pm$ 5.19 immediate post-program.

This finding is correspondent to Shaban et al., (2019) who studied " Effect of an Educational Program on Perception and Practices of Nursing Students Regarding the Cord Blood Collection Technique and Stem Cells" in Tanta, Egypt $(n=120)$ and illustrated that, there was a statistically significant improvement for all knowledge post educational Program. Also, the present study was in the same line with Amin et al., (2016) who revealed that majority of staff nurses (90\%) had poor knowledge and only $10 \%$ had average knowledge regarding umbilical cord stem cell therapy.

The above results were on the contrary to a study done by study done by Venugopal et al., (2016) titled as " assess the knowledge and attitude of nurses regarding stem cells and tertiary care facility" in India and reported that $42.86 \%$ of studied sample (56) had moderate knowledge regarding stem cells and umbilical cord blood banking.

This improvement might be as a result of an educational program sessions and the instructional booklet distributed to nurses used as an ongoing reference as well as nurses' interest to learn and acquire knowledge about the umbilical cord blood banking and its barriers.

The results of current study displayed that, about less than tenth have positive attitude pre-program and raised to the majority of studied sample immediate post-program.

The above finding is correspondent to Shaban et al., (2019) who reported that about two-thirds of the students $(n=120)$ had a negative attitude related to the cord blood collection and stem cells in the pre-test, while it was improved immediately posttest. Also, this finding is partially correspondent to 
Azzazy \& Mohamed, (2016) who assess "The effect of educational program on nursing students' knowledge and attitude regarding stem cell therapy" and reported that $56 \%$ of their sample $(n=53)$ had positive attitude toward stem cell therapy before the program which changed to $94 \%$ post program.

On the contrary of the present study results Fadeel, et al., (2018) who reported that no statistical significance difference between attitude in pre, and posttest assessment. Additionally, Leng et al, (2016) who study "Association between nurses' knowledge and attitudes toward stem cell application in medicine" who carried out a study in Malaysia, revealed that $86.6 \%$ of their nursing students $(\mathrm{n}=97)$ showed good attitudes toward stem cells therapy.

Moreover, the current study illustrated that there was a highly statistical significant difference between the results of immediate post-test compared to pre-test in favor of immediate post-test regarding all items of umbilical cord blood banking with $(\mathbf{p}<\mathbf{0 . 0 0 1})$. This may be due to the programed sessions provided the participants with valuable information that can positively affect their beliefs which in turn positively affect their attitude.

The present study demonstrated a positive highly statistically significant correlation between total knowledge score and total attitude score at pre and immediate post program $(\mathrm{P} \leq 0.001)$.

The present study findings supported by Patyal et al., (2018) who stated the correlation between knowledge and attitude with Similar results have been observed in another study done by Venugopal et al., (2016) who illustrated that, there was a positive correlation between knowledge and attitude scores of nurses $(\mathbf{p}<\mathbf{0 . 0 1})$. Additionally, the present study findings supported by Tork et al., (2018) who conducted study about "Stem cells: knowledge and attitude among health care providers in Qassim region, KSA." and revealed a significant relation between the level of knowledge and the attitude level regarding stem cells.

On contrast of the present study results, Shaban et al., (2019) that illustrated that there were no significant differences with a positive correlation between the total knowledge score and total attitude score throughout the periods of the study. dditionally, Leng et al, (2016) mentioned that there was a poor association between the undergraduate nursing students' knowledge and attitude score.

The present finding due to effect of level of knowledge on their attitude, lack of knowledge cause negative attitude while increase level of knowledge help in improving attitude.

The present study reveals that, there was a highly positive statistical significant relation between studied nurses' total knowledge and age, educational level and years of experience preprogram $(\mathrm{P} \leq 0.001)$. Also, there was a highly positive statistical significant relation between studied nurses' total knowledge and years of experience immediate post program ( $\mathrm{P} \leq$ 0.001). Additionally, there was a statistical significant relation between studied nurses' total knowledge and educational level post program $(\mathrm{P} \leq 0.05)$.

This finding of study was partially agreement with Mohammed \& ElSayed.,(2015) who stated a positive statistically significant correlation total knowledge scores and educational level. But, there was a negative statistically significant correlation between total knowledge scores and age, as well as between total knowledge scores and years of experience at different times of assessment.

These results were disagreed with Amin, et al., (2016) who revealed that, there 
was no association found between knowledge score and the selected demographic variables like age, year of experience and educational status.

The current study illustrated that there was a highly positive statistical significant relation between studied nurses' attitude and age preprogram. Also, there was a highly statistical significant relation between studied nurses' attitude and years of experience immediate post program $(\mathbf{P} \leq \mathbf{0 . 0 0 1})$. Additionally, there was a positive statistical significant relation between studied nurses' attitude' and years of experience preprogram and educational level pre and immediate post program (P $\leq \mathbf{0 . 0 5})$.

The present study findings partially supported by Fadeel, et al., (2018) who founded significance differences between attitude and years of experience, but no significance differences between attitude and level of education. Also, partially agreement with Mohammed \& El-Sayed., (2015) who stated a positive statistically significant correlation total attitude scores and educational level. But, there was a negative statistically significant correlation between total attitude scores and age, as well as between total attitude scores and years of experience at different times of assessment.

The chance of gaining information and accept positive attitude improved with age and more years of experience.

Finally, the above mentioned results can be concluded as there was a highly statistical significant difference between the results of post-test compared to pre-test in favor of post-test regarding maternity nurses' knowledge and attitude with $(\mathbf{P} \leq \mathbf{0 . 0 0 1})$. So, there is a need to step up awareness creation for umbilical cord blood banking through, mass media, more educational programs or university and pre- university curriculum.
Also, it is necessary to update the nurses knowledge on the trends and new technology.

\section{Conclusion}

Application of an educational program on umbilical cord blood banking and its barriers have a positive effect on maternity nurses' knowledge and attitude regarding the umbilical cord blood banking and its barriers. There was highly statistical significant improvement of total knowledge between pre and immediate post-program $(\mathrm{P} \leq 0.001)$. There was a highly statistical significant difference between the results of immediate post-program compared to pre-program in favor of immediate post- program in all items of attitude regarding umbilical cord blood banking and its barriers $(\mathrm{P}<0.001)$. There were highly a positive statistically significant correlation between total knowledge score and total attitude score at pre and immediate post program ( $\mathrm{P} \leq 0.001)$. Therefore the study hypothesis was supported and the aim was achieved.

\section{Recommendations}

$>$ Adequately planned in-service training programs related to umbilical cord blood banking must established to develop nurses' knowledge, attitude in order to suit newly developed concepts in care.

$>$ Booklet regarding cord blood banking should be available in Obstetrics and Gynecological departments to be accessible to all nursing staff.

$>$ Integrate the umbilical cord blood banking and cord tissue as a new technological advancement in the nursing curriculums

\section{Recommendation for further researches:-}

Further studies are required to identify and investigate maternity nurses 
concerns regarding their practice of umbilical cord blood collection technique.

Replication of the study on large sample size in different setting for generalizing the findings.

\section{References}

Amin, A., Kumary, V., \& Vijiparasad, C. (2016). Knowledge regarding umbilical cord stem cell therapy among staff nurses with the view to develop self-instructional module. IJHSR, 6(11), 209-213.

Azzazy H., \& Mohamed H., (2016). Effect of educational program on knowledge and attitude of nursing students regarding stem cells therapy, IOSR Journal of Nursing and Health Science; 5 (2): 75-80.

Fadeel O., Moustafa M., \& Hafez A. (2017). Effect of an educational Guideline on Maternity Nurses Knowledge regarding process of cord blood collection; Minia Scientific Nursing Journal; 2 (1):15-20.

Fadeel O, Moustafa M, Hafez A.(2018). Effect of Guideline on Maternity Nurses Attitude about Umbilical Cord Blood Banking and Its Barriers;7(2):43-47.

Gholap M., Mohite M., Mohite V., Chendke M.., Hiremeth M., \& Choudhari M. (2018). Study to Assess the Awareness Regarding Umbilical Cord Stem Cell Therapy among Health Team Members in Tertiary Care Hospital, Karad. International Journal of Health Sciences \& Research (www.ijhsr.org) Vol.8; 205-212 ISSN: 2249-9571.

Khalil A., \& Sharshor S. (2016). Pediatric Nurses Knowledge, Awareness and Attitude towards Application of Stem Cells Therapy in Children. IOSR Journal of Nursing and Health Science, 5(4), 88-96.

Leng L., Keng, S., Ahmad W., \& Cheng T., (2016). Association between nurses' knowledge and attitudes toward stem cell application in medicine, the Malaysian Journal of Nursing; 7(3): 3-9.

Mansour, S., Gouda, A., \& Ibrahim, A. (2020).Effect of an Educational Program on Nurses' Knowledge and Attitudes Regarding Umbilical Cord-blood Stem Cells Preservation: Journal of Nursing and Health Science (IOSR-JNHS) Volume 9; pp78-89, Issue 1 Ser, ISSN: 2320-1940.

Mohamed H and El-Sayed H., (2015). Knowledge and Attitude of Maternity Nurses Regarding Cord Blood Collection and Stem Cells: An Educational Program. Journal of Nursing Education and practices, 5(4)58-69.

Moustafa, M \& Youness, E. (2015). Nurses' knowledge about umbilical cord blood banking and it's barriers. IOSR J Nurs Health Sci, 4(2), 44-53.

Patyal N, Kaur R, Singh R, Reetu A, Ritu R, Kaur R, Kumar S, Kaur S, SarinJ(2018). A Study to Assess the Knowledge and Attitude of Nurses Regarding Stem Cell and Umbilical Cord Blood Banking in Selected Hospital of Ambala, Haryana. The Pharma Innovation Journal.;7(6):154-159.

Peberdy, L., Young, J., Massey, D. L., \& Kearney, L. (2018). Parents' knowledge, awareness and attitudes of cord blood donation and banking options: an integrative review. BMC pregnancy and childbirth, 18(1), 1-21.

Philip N, Devis (2017). Improve the Knowledge and Attitude of Antenatal Mothers Regarding Umbilical Cord Stem Cell Banking.IJRSR. 8(6):17303-17308.

Pinto V, Pushapaveni N. (2018). Study to Evaluate the Effectiveness of Structured Educational Program Regarding Collection of Cord Blood for Stem Cell Therapy in Terms of Knowledge among Staff Nurses in Selected Hospitals at Bangalore.Asian Journal. Nursing Education and Research.;8(1):7-10.

Rucinski, D., Jones, R., Reyes, B., Tidwell, L., Phillips, R\& Delves,D.,(2010).Exploring opinions and beliefs about cord blood donation 


\section{Umbilical Cord Blood Banking and its Barriers}

among Hispanic and non-Hispanic black women. 50(5): 1057-1063.

Sahoo, R., \& Rana, L. (2020). Pregnant women's Knowledge and Attitude about Stem Cells and Cord Blood Banking. Asian Journal of Nursing Education and Research, 10(4), 452-456.

Shaban R., Elkazeh E., \& Mohamed N. (2019). Effect of an Educational Program on Perception and Practices of Nursing Students Regarding the Cord Blood Collection Technique and Stem Cells. ISSN: 2320-1940 Volume 8, PP 28-41.

Tork, H., Alraffaa, S., Almutairi, K. J., Alshammari, N. E., Alharbi, A. A., \& Alonzi, A. M. (2018). Stem cells: knowledge and attitude among health care providers in Qassim region, KSA. International Journal of Advanced Nursing Studies, 7(1), 1-7.

Venugopal A, Joshi P, Deka D and Seth T(2016). Knowledge and attitude of nurses regarding stem cells and umbilical cord blood banking in aselected tertiary care facility Asian Journal of Nursing Education and Research.; 6(2):240-244. 
تاثير برنامج تعليمى على معلومات واتجاهات ممرضات الامومة عن بنك دم الحبل السرى وعوائه

$$
\text { نهلة توفيق احمد- هند صلاح الدين تحمد - رحاب محم عبد الهادى- رحاب سليمان عبد العليم }
$$

دم الحبل السري هو المصدر الأكثر شيوعًا للخلايا الجذعية المكونة للام ، وقد تم استخدامه كبديل لنخاع

العظام للاستخدام العلاجي في امر اض الدم والجهاز المناعي واضطر ابات التمثيل الغذائي بسبب مصدره الغني بالخلايا الجذعية. بنك دم الحبل السري هو عملية جمع وتخزين دم الحبل السري بعد و لادة الطفل مباشرة. لذلك هدفت هذه الدراسة إلى تقييم أثر برنامج تعليمي على معرفة وممرضات الأمومة عن بنلك دم الحبل السري و عو ائقهوقد أجريت هذه الدراسة على · . 1 ممرضة بقسم أمر اض النساء والتولبد بمستشفى جامعة بنها و كثفت النتائج عن انه كان هناك تحسن كبير في المعلومات الكلية بعد التذخل. كان هناك ارتباط ذو دلالة إحصائية بين المجموع الكلي للمعلومات والمجموع الكلي لاتجاهاتهم قبل وبعد التدخل. كما أوصت الدراسة بوضع بر امج التدريب أثناء العمل مخطط لها بثكل مناسب والمتعلقة ببنك دم الحبل السري وحو اجزه لتطوير معلو مات الممرضات وسلوكياتهم من أجل ملاعمة المفاهيم المطورة حديثًا في الرعاية وايضا توفير كتيب خاص ببنك دم الحبل السري و عو ائقه في أقسام التولبد وأمر اض النساء ليكون في متناول جميع طاقم التمريض. 